\title{
Moqim Khani Biography Importance in the Eyes of Historians and the Study of References Related to Topics
}

\author{
Mohammad Geraili Kerapi* \\ Academy of Sciences, Institute for Humanities, Khorog, The Republic of Tajikistan \\ *Corresponding Author; Email: m.geraili43@yahoo.com
}

Doi:10.5901/mjss.2016.v7n2s2p193

\begin{abstract}
Mogim Khani biography written by Mohammad Yousuf Monshi such as handwritten and authentic reference as the basis handwritten in view of historians has attracted particularly European writers. Historians who have studied an investigation into the sources are the German scholar, "V.Vambery" and famous professor of the University of St. Petersburg, "Synkavosky" who published a part of Moqim Khani subjects with explanations in French in a volume of $132 p$ and the renowned historian "A.Symyanof" published this reference in the Russian language. Here we can mention the sources that have had the issues related to Mogim Khani biography, including: Bebernameh, Zahireddin Baber, and the other Bahrol Asrar Fi Manaqebol Akhyar Mahmoud Ibn Vali, Maskharol Belad, Bukhara history, the history of the inlux of nomads Cumania to Transoxania, Habibol Seir and other credible sources. And an issue that has been mentioned is tools and oppositions of the rulers of Bukhara and Balkh, and the role and influence of religion in the political structure of the state and government representatives, and also the role of landowners and nomads who are considered stakeholders in the system of government and they are important in the structure of governmental system. The comparison of Mogim Khani biography with other sources in the government structure of Transoxania and Bukhara Khani are subjects which are cited by researchers. It is hoped that it is useful.
\end{abstract}

Keywords: Shaybanids, Transoxiana, Bukhara, Safavids

\section{Research Structure}

In every research, a researcher must explain the method of own work how their data is collected. In this study, the method of library or document is used. In this method, the researcher by referring to all sources identified has collected the contents needed and taken notes and in writing research he has used them.

The tool of data collection of the researcher in the library method is all printed documents such as books, encyclopedias and dictionaries, magazines, newspapers, dictionaries, yearbooks, published interviews, research letters, books of scientific conferences, printed texts indexed in databases any source identified in print.

In studies which naturally do not seem to have a library method, researchers are also inevitably the application of its research library method. In this research group, including descriptive, correlational, and experimental and so on, the researcher must study literature and history of the problem and case studies. As a result, he should use the library method and he records and maintains the results of his studies at the appropriate tools such as paper, table and form, and maintain and in the end, he must act against their classification and exploitation.

The first step in library research skills is to learn how to use the library; it means that researchers must know how to use papers and to register book characteristics, how to search for books in the library and also computers, and the rules of operation and order the book. To do this it is necessary that by studying the sources and using the experiences of others and also tips of librarians acquire the needed skills which in the research conducted by the researcher all this case has been used. And the result is that the researcher has conducted a thorough investigation.

\section{Introduction}

Moqim Khani biography written by Mohammad Yousuf Monshi such as handwritten and authentic reference as the basis handwritten in which the historical events of the 16th century to the early 18th century Transoxania and Khorasan, especially Bukhara Khani have been discussed enjoys a high scientific degree. However, training topics of the sources seems to have attracted historians, particularly European writers. A German researcher "V. Vambery" when writing his historical work, the history of Bukhara or Transaksanya, some of the contents of treatise of Mohammad Yousuf Monshi have been used. Translation of a part of Moqim Khani biography by the researcher A.N.K.Malinsky in 1824 and a famous 
professor of the University of St. Petersburg, "Synkavosky" who published a part of Moqim Khani subjects with explanations in French in a volume of $132 \mathrm{p}$ as a source of knowledge for students and the renowned historian "A.Symyanof" published this reference in the Russian language. Here we can mention the sources that have had the issues related to Mogim Khani biography, including: Bebernameh, Zahireddin Baber, and the other Bahrol Asrar Fi Manaqebol Akhyar Mahmoud Ibn Vali, Maskharol Belad, Bukhara history, the history of the inlux of nomads Cumania to Transoxania, Habibol Seir and other credible sources. Another issue that is mentioned in the study by the researcher is to discuss historical events of the 16th and beginning of the 18th century and analysis in Transoxania and investigate these events and match it with linear resources and tools and oppositions of the rulers of Bukhara and Balkh, and the role and influence of religion in the political structure of the state and government representatives, and also the role of landowners and nomads who are considered stakeholders in the system of government and they are important in the structure of governmental system. News and detailed information of the writer in this era is additional benefits of this source. The comparison of presentations in Mogim Khani biography with the contents provided by Western scholars in the field of governance of Transoxania and Bukhara Khani is the materials which are referred to it by the researcher and for researchers interested in studying historical events of Transoxania and Bukhara Khani are at this point of time are useful. Moqim Khani biography such as handwritten and authentic reference as the basis handwritten in which the historical events of the 16th century to the early 18th century Transoxania and Khorasan, especially Bukhara Khani have been discussed enjoys a high scientific degree. The first person who had given this information to pamphlet had been Russian ambassador "F. Negri" that had come to Bukhara in the years 1820-1821 and Amir Bukhara Haider (1826-1820 AD) gave him a copy of the book and he took it to St. Petersburg. In 1832, the British ambassador in Bukhara Alexander Burns possessed a copy of this work and took it to England (Moshi, 1958).

European scientists through it found this source of identification based on the version which Negery had brought from Bukhara to St. Petersburg.

In 1824 by helping the famous orientalist, professor of the University of St. Petersburg, "Synkavosky" who published a part of Moqim Khani subjects with explanations in French in a volume of $132 \mathrm{p}$. The book which Synkavsky issued, many years to European scientists as a guide only served to the history of Transoxania (Bartold, 1977).

In 1854, the researcher "Marley" published a list in the library of the Great Seal Great Britain's Asian population, which is described by Mohammad Yousuf Monshi and about the work the German researcher "F Tyfyl" has written articles for (Malynsky, 1613 AD). A German researcher "V. Vambery" when writing his historical work, the history of Bukhara or Transaksanya, some of the contents of treatise of Mohammad Yousuf Monshi have been used. Translation of a part of Mogim Khani biography by the researcher A.N.K.Malinsky (Malinsky, 1613) and A.A.Simiyanof was published in Russian (Simiyanof, 1907). In1956 A.A.symyanf academic perfectly translated this work into Russian and published in Tashkent. Some of Moqim Khani biography Mohammad Yousuf Monshi have been used by the Tajik scholar (Saeed F, 2012), Iran (Kelazery, 2010) Uzbekistan (Abdul Rahim F., 1966) and by others.

Iranian scholar "Fereshteh Sarafan" on the editions of this work which are in the libraries of Iran published the critical edition of the work (Monshi, 1979).

Regardless of whether some contents of Moqim Khani importance have been used by researchers but the source, such as academic books have been investigated. That is why a comprehensive research work for science today that include ambiguous in some cases in peoples of Central Asia in the 16th century and beginning of the 18th century and it is an important content and the importance of exercise science.

those matters associated to the importance of Mogim Khani biography is to compare its contents with valid historical sources by researchers and one such source that belongs to this period, it is the work of Kamaleddin Banaei 01453 and 1512 Sheybani Nameh in which there are the influx of nomadic tribe to Transoxiana from them and plunder their cities and brutality and looting by local people and so much information out there. In this work, important information established in the name of the nomadic tribes and the names of their leaders, who Sheibani Khan invaded Transoxiana and they helped to bring to conquer the place, there is abundant information. One of the versions of this work are reserved in Dushanbe (Simiyanof, ! 907) and another in Tashkent (Akram F., 1967).

Zahirodin Babar book "Babar Nameh" is one which has been given in this and to the Sheibani Khan. Some scholars consider such that this work belongs by Mohammad Saleh and wrote it with command of Shaibani Khan. This work is of three kinds: the first part includes Genghis Khan, in the second part of the history, Tamerlane and the third part is devoted to the history of Sheibani Khan. The first two parts of the book have some features of taking note from another book and the part three is the observations of the author. Critical text is published by Akram F.M. (Akram. F., 1967).

Another important source which is devoted to this era is the work of Fazlollah. Roozbahan Esfahani "Bukhara Guesthouse". Its author was a known Sheikh and served in the court of rulers and had great influence in the court and had a lot of friends. He was aware of all his time of political events and had mentioned their work in these events. In this 
work, a lot of information is mentioned in addition to Sheibani and Safavid relations. This is due to the efforts by Manouchehr Sotoudeh has been published in Tehran (Khonji, $1341 \mathrm{SB}$ ) its translation to the Russian language is available (Jalil F, 1778). The work of Mir Habib Alseir written in the years 1521-1524 are set to invade Shaibani Khan in Khorasan and its conquer has a lots of information. The value of this work is that the author to the court of Herat has had a close relation and sees many events that give a good knowledge to Safavid relations the first Sheibani. This work of Mirkhand in Iran has been published in four volumes (Khandmir, 1360 p). The book of zahirodin Babar, Babar Nameh, is the one that much information has mentioned in this work of political events from reliable sources of this political era Transoxania and Khorasan and India until the 1592. The book has been published in Tashkent (Zahireddin Babar, 1960) and there is also a Russian translation (the same source). Another source of information established in the first half of the 26th century is the book of "Jahangoshaie Emperor" who its author is unknown. This work was written between 1541and1548. In this work, the important information in addition to war and political conflict Safavi was mentioned by Sheibani. One particular feature of this book is that the author registers his thought, opinion and conclusion when describing events. This work has been issued in Islamabad in 1986 (Khan, 1986). The work of Amir Mahmoud Khandmir, the son of author of Habib Alseir as the history of Shah Ismail and Shah Tahmasb Safavi (under Habib Alseir) that registered validated claims in incidents of political Transoxania and Khorasan, and this book is published in Iran (Khandmir, 1380). Rashidi history of Mirza Mohammad Daghalat known as Heidar, this work of two books is in the first book of Chagatai history of Mongolia and Kashgar including from the period of Teimour to Abdolrashid Khan and the second book has been the notes of own author. Its volume is four times greater than the first book and this book has been released in Iran (Dogholat, 2004). There are some parts of it translation into the Russian language (Jalil F., 1988). The book of Ahmad ibn Sharaf al-Din Hussein Qomi, a summary of Tavarikh dedicated to the history of governance of Safavids and many cases are mentioned in it established for Safavid relations with Sheibani. It enjoys the scientific importance. The author in Khorasan is a high official in the court of Shah Tahmasp. After the death of Tahmasp, by order of Shah Ismail, began writing this work and finished it in 1590 and gave this book to Shah Abbas and this book has been published in Iran (Qomi, 1980). The scientist history of Abbasi belongs to Alexander Beg Turkoman. The author is written in three volumes and some contents with his own observations. In the first volume, it is based on the copy of the written sources, and includes the history of the reign of Shah Abbas I from the beginning of his ancestors. The second volume of the court is dedicated to the history of the rule of Shah Abbas I from 1588 to 1669. The second volume is devoted to the reign of Shah Abbas for twenty years. Copies of this work are reserved in many libraries (Stari, 1872). The translation of parts from this source has been published with explanations to the Russian language by Viliyaminav Zirminav(Zirnav, 1872). The book was published in Iran by Iraj Afshar (Afshar, 1999).

Another work devoted to this period is the work by Mahmoud Ibn Vali called "Bhrolasrar Fi Manqebol Alakhyar" that is written to the governor of Balkh Noor Mohammad Khan. This work has been composed of 7 volumes. Volume I including the historical subjects and Volume VI established to the Mongol history to the reign of Nadir Khan and they are available. A copy of the book is reserved in the library of India Office in Great Britain under the number 575 and we have it photocopied and there is the translation of the part of the geography of this work into the Russian language (Mahmoud Ibn Valy, 1977). The author work of the second half of the 15th century and the first half of the 16th century, Mohammadyar Ibn Arab Qatghan, Maskharalbelad, who the influx of nomadic tribes Cumania to Transoxania and Khorasan and Sheibani's struggle with the Safavids and Ashtarkhany relations with neighboring countries have been mentioned. This work has been published in Iran by Nadereh Jalali (Arab Qatghan, 2006) and is also translated into Uzbek language (Bykjanav 2009). In the work of Sheikh Juybari Abu Abbas Mohamma Taleb, Matlabot Taebin (Abu Taleb, 1965). About activities of Juybar sheikhs who were involved in social and political life of the state is given important information. This book is not published already. Three handwritings are preserved in East Institute of the Academy of Sciences of Uzbekistan (Akhmdvf, 1947) and one version in Dushanbeh. Another important work of the scientist is called the Safavid votes which in this book there is much information on Safavid relations with Sheibani who to unravel the various issues are material belonging to the history of the 16th century and this work is published in Iran (Shokri, 1984).

Another important work is the two-volume book from Mohammad Amin Ibn Zaman Bukhari Soufi "Tavarikh environment". This work is based on 37 writing work and gives some information about the history of the reign of Khans of Bukhara. And important information has been mentioned about the rule of Subhan Quli Khan 1680-1702. The version of the book is reserved in East Research Institute of the Academy of Sciences of the Republic of Uzbekistan (Mukalla, 1957). Another important work which belongs to Abidollah Nameh is written by Mir Mohammad Amin Bukhari in which the history of the ruling era Abidollah Khan and its translation is available into Russian language (Amin Bukhari, 1957). Another source is called "the history of Abulfei Khan", which is known by Abdul Rahman Dolat under the pen name of fortune. This work devotes to the political history of Bukhara at the beginning of the 18th century in which about the 
beginning of instability in government Khani Bukhara and started casting internal conflict between the rulers of this country have been informed and to this book for publication paper is sent (Abdol Rahman Dolat, 1957). This work has been translated into Russian and publication (Taleh, 1959). Khajem Quli Beg Balkhi, who is known by the pen name of Qipchaq Khani, wrote a work with Qipchaq history that was written in the year 17 AD. In this work some information was mentioned about the history of Balkh and Afghanistan. The work of the researchers has been studied a little and there are seven versions until now (Mukalla, 1925). The work of Khajeh Muhammad Baraa which is known with the pen name "Samandar Khajeh", is by the command of kings established to the history of Transoxiana at the end of the 17th century, there were mentioned important information. Contemporary authors for rulers of Bukhara were Abdul Aziz Khan and Subhan Quli Khan which had a close relationship with them and have participated in the campaign. In the work established to political relations of Transoxiana with Khani Gary Khiva at the end of the 17th century, there abundant information has been collected. One or more copies of this work in Tashkent was reserved (Tirmidhi, 1926) and there is also a Russian translation. In the three-volume book of Mohammad Kazem "on Naderi history" a lot of information has been collected to the rule of Iran's ruling establishment Nader and his campaign to Bukhara and Khiva. In this book except political issues about social and economic conditions of the course, there are valuable information and microfilming has been published (Mohammad Kazem-1960). Some of the material in this book has been published in the Russian language (Ivonov.! 987). Another work of Taj al-Tawarikh is written by Mohammad Sharif Ibn Mohammed Taqi which there are available about important issues on Transoxania which a version of it is reserved in Dushanbeh (Mohammad Naqi, 1982) and Tashkand reserved (Mohammad Sharif, 2092 AD). Another important resource that belongs to this period is the monument work of Mirza Shams Al-Bukhari ", Bukhara and Kokand and Kashgar history" written in 1859. The importance of this book is that authentic historical sources are included in this book and it is published in a collaborative effort of Mohammad Akbar Asheq (Shams Bukhari, 1998). Other books of the "Burhanuddin Kooshki are Qatghan and Badakhshan" and this book is published and written into the Russian-language by Voudinsky (Kooshki, 1966). The book of Muhammad Salim Ibn al-Rahim, Kashkool Salimi including valuable contents is in Tashkent (Mohammd Salim, 2091), from the authoritative source on this period treatise on rank and title and duties of holders of Bukhara in the middle age which is available important information in its administrative structure Khani Bukhara. This work has been published by Symyanof (Symyanof, 1948) and there is important information about the history of Badakhshan in the Age 17-19 and political relations with different regions of Transoxania this area are mentioned in this book. The book has been published by Baldyv (Mohammd Bakhshi, 1959) and a lot of information established to these issues in the itinerary of tourists Russian, European (Wired, 1669) and various other collections has been gathered in this regard.

\section{Conclusion}

Moqim Khani biography written by Mohammad Yousuf Monshi such as handwritten and authentic reference is as the basis handwritten including important information in historical events of Transoxiana and Bukhara Khani in in the 16th century to the early 18th century which has been written by order of Muhammad Moqim Khan, an autonomous governor of Balkh and written by Mohammad Yousuf Monshi with an artifact prose which is with the accent of Bukhari and a reliable source of historical events mentioned in the rule of Shaibanid and Ashtrkhanyha is in political geography of the region. The exact source of the rare knowledge and its importance, especially my observations when compiling some events has caused great Iranian historians consider to attract European and Russian. Here, by introducing researchers who have translated this work into different languages, we have taken an important step in the introduction of this important historical work and also by introducing different books which have related materials with this biography and is written by researchers on topics related to the Russian and Latin Persian language, the valuable situation of this scarce resource made clear this rare handwriting, and their place in the libraries of Russia and Central Asia, Iran and Europe have been shown and the idea of positive thinkers on the role of the authority in the historiography of the Middle Age and Bukhara Khani and Transoxania is quite evident. The importance of this research is that the results can set up some historical events which has been in this era in Transoxania and Khani Gary Bukhara established in countries bordering and which it has been pointed out in less source and paves the way the initial step for researchers who devote themselves to research historical events in Transoxania and Khorasan at this point. The results of this research could solve some historical issues related troubleshooting when writing scientific works in this period too. In this paper, it has been tried that by studying a detailed examination of different sources and precise measurement of the position of significant historic and special place among this period of history we realize that this is an important step for the researchers. 


\section{References}

Monshi, M. U. (1956). Moqim Khani biography. translated with an introduction and description of the Tajik language and gestures by Professor II Symyanof. Tashkent.

Bartold, V.V. (1977). Learning history in East Europe and Russia. c. 9. Moscow. Novak.

Vambery, G. (1873). Bukhara or Transaksanya history, from ancient times to the present. Translated by A. A. Apolavsky vol. 1 - 2. St. Petersburg.

Malinowski, N. G. (1900). Taromar. Tashkent on behalf of Khan Bukhara Emamgholi Khan in 1613. Tashkn.

Symyanof, A. A. (1907). The rise of Changiz Khan and his conquers in the book of Vidamast in Turkestan.

Saeed, F. (2010). Political, social and economic situation of Bukhara in the 17th century and the first half of the 18th century. founding Khani. Dushanbeh.

Kamal, H. (2006). The history if influx of nomads Cumania to Transoxania and Khorasan _8 $8^{\text {th }}$ century. Dushanbeh. 2012. absent .A. Khatlon history from the beginning until today. Dushanbeh.

Nikzad, K. (2010). Criminal relations with the Safavid in the 17-18 century in the Journal of Culture 2010. No. 5 - 6.

Abdul Rahim, F.M. (1966). Description of landlord occasions in Bukhara in the 17th century and the first half of the 19th century Tashkent c 1.

Ahmed, F.B.A. (1982). Balkh history (the 17th and the first half of the 18th century) Tashkent.

Mir Khand, A.M. Alseir, H. (2002). the efforts of Jalaleddin meetings 4c, Tehran. Iran.

Baber, Z. M. (1961). Baber Nameh. in the Chagatai language. Tashkent.

Baber, Z. M. (1958). Baber Nameh. in the Russian language. translated by M.Seli. Tashkent.

Jahangoshaie Khaqan (no author). (1986). An introduction by Doctor Mozaffar. Islamabad.

Khandmir, A. M. (1992). the history of the Safavid Shah Ismail. Shah Tahmasp (under Habib Alseir) Introduction and explanations by Doctor Mohammad Ali Jarrahi. Tehran. Iran.

Haidar Dogholat, M. M. (2005). Rashidi history, by considering Abasgholi Ghaffari. Tehran. Iran.

Haidar Dogholat, M. M. (1988). the history of Rashidi translated from Persian to Russian language .R.P. Jalil Of and .L.M Epifenaveh. in Central Asia Income ages 10-19. Tashkent.

Judge Ahmad, S. H. (1981). Qomi, briefly illuminated Tavarikh with good efforts. Tehran. Iran.

Monshi, M. U. (1979). Moqim Khani biography. Background and Description of Fereshteh Sarrafan, Tehran. documentary heritage.

Banaei, K. Sheibani Nameh. handwritten by A.A. Symynof, Institute of Archaeology and Anthropology historyby Ahmad Danesh, Academy of Sciences of the Republic of Tajikistan.

Banaei, K. Sheibani Nameh. handwritten by East Institute of the Academy of Sciences of the Republic of Uzbekistan. No. 844.

The history of Selection of Mir Mohammad Amin Bukhari, (1957). Ubaidullah Nameh. a translation of Tajiks in Russian. A.A.symyanof. Tashkent.

AbdulRahim Of. M.A. (1957). Rahman Khan Dolat history. established as the basis of political and economic decline Khani Gary Bukhara in the 18th century in the Journal of the Academy of Sciences of the Republic of Uzbekistan News. No. 3.

Abdol Rahman Khan Taleh, (1959). the history of Abolfeiz Khan. the translation of the Tajik to Russian. H.H. Symyaof. Tashkent.

Mykolokhay Mukalla.N.D. (1925). Description of handwritings, editing 3. pp. 146-148 Ramskyvnoch.A.A. Handwritings of versions of Persian. Turkish. Tatar. and the Arabic Age Pittsburgh.

Samandar Khajeh Tormozi, by the order of kings, handwriting of Institute of the Academy of Sciences of the Republic of Uzbekistan. No. 1437-5792.

Samandar Khajeh Tormozi, a photo of handwriting version translated from Persian into Russian with introduction and description of Saladin Of.V.V. Moscow. 1971.

Kazem, M. (1965). A letter of Nadari. vol. 1 - 2. the publication of the text. introduction and writing Mykolokhay Mukalla. N.D. Moscow. 1960, vol. 1, 1965.

Petro, P. E. (1961). Mohammad Kazem. Nadir Shah's invasion of India. Moskof 1961.

Ivonof. P. P. the rest of translations of books by Mohammad Kazem in materials in Turkmen history and Turkmenistan. C. Moscow. Leningrad.

Mohammad Sharif bin Mohammad Taqi, crown Tavarikh, handwriting Institute of Language and Literature East and the legacy of linear Academy of Sciences of the Republic of Tajikistan, No. 22-82.

Mohammad Sharif bin Mohammad Taqi. Taj Tavarikh. handwriting East Institute of Science. Republic of Uzbekistan. No. 2092.

Bukhari, M. S. (1998). the history of Bukhara, Kokand and Kashgar with the efforts of Mohammad Akbar Asheq. Tehran. Iran.

Koushki, B. (1926). translated from Persian to Voudonsky Russian P. with the introduction A. A. Tashkent.

William Minav, V.V. Research conducted for the king and the princes Qasemavy. Eastern Branch of the Russian Empire St. Petersburg ancient population. 1862-1866, the second type.

Turkoman, E. B. (2000). the history of Abbasi. foreword by Iraj Afshar books Vol. 1 - 2. Tehran. Iran.

Mahmoud Ibn Valy, Bahr al-Asrar fi Manaqeb Alakhyar. a photocopy of India Office Library in Great Britain. No. 575.

Mahmoud Ibn Valy. Bahr al-Asrar fi Manaqeb Alakhyar. an introduction of translation and explanation by. B.A. Ahmaov. Tashkent 1977.

Arab Qatghan, M. (2007). Mskhralbelad, with effort. N. Jalali. Tehran. Iran.

Arab Qatghan, M. (2009). Mskhralbelad, M. (2009). translated from Persian into Uzbek language. E.Bikjananov. V.D. Sangiaveh. Tashkent. 
This book is on behalf of the researcher B.B. (1927). Ivanov in the book of Juybari Sheik Khajegi. established to the history of feudal agrarian in Central Asia in the eras 16-18, the Moscow. Leningrad. 1954 and the paper of Vyatyken, Juybari Sheikh on in collection of. Adoljaman. Barthold. Tashkent. p. 3. 36.

For its brief descriptions. see a list of Eastern handwriting of Academy of Sciences of the Republic of Uzbekistan. c. 1132. vol. 2 FC 325. BuovAhmadov. historical literature p. 188-194.

Mohammed Talib, A. A. Matlab Altalbyn. handwriting of Institute of Language. Literature East Academy of Sciences of the Republic of Tajikistan. No. 44.

Safavi realm of ideas, (1984). with emphasis Yadu'llah Shokri. Tehran. Iran.

Mohit Altavarikh. Handwriting of East Research Institute of the Academy of Sciences of the Republic of Uzbekistan Tavarikh. No. 835.

About its brief descriptions. (1967). see the list Academy of Sciences of the Republic of Uzbekistan linear line G 1. Mykelokhay Makalay. N.D. Handwriting and editing descriptions. critical text. M. Akram. F. Tashkand.

Roozbahan Khonji, F. (1963). hostel of Bukhara dedication and efforts by Manouchehr Sotoudeh. Tehran. Iran.

Guesthouse of Bukhara. Moscow 1978. Translation. introduction and description of Jalil Of. R.B. Moscow 1978. 